COMPETITOR: Jurnal Pendidikan Kepelatihan Olahraga

Volume 12 Nomor 2, Juni 2020

e-ISSN: 2657-0703 dan p-ISSN: 2085-5389

(C) (1) This work is licensed under a Creative Commons Attribution

4.0 International License

\title{
PENGARUH PERMAINAN KECIL TERHADAP MINAT BELAJAR SISWA DALAM PEMBELAJARAN PENDIDIKAN JASMANI KELAS VIII DI MT's AL-AHLIYAH
}

\author{
Muhammad Gilang Ramadhan ${ }^{1^{*}}$, Citra Resita $^{2}$
}

\author{
Keywords : \\ Permainan Kecil; Minat \\ Belajar.

\section{Corespondensi Author \\ ${ }^{1}$ PJKR, FKIP, UNSIKA, gramadhan375@gmail.com \\ 2 PJKR, FKIP, UNSIKA, citra.resitas@yahoo.co.id}

Article History

Received: Mei 2020;

Reviewed: Mei 2020;

Accepted: Juni 2020;

Published: Juni 2020.

\begin{abstract}
In this research The problem in this study is the low student interest in learning physical education class vii at MT's Al-Ahliyah. This study aims to determine the effect of small games on student interest in learning. This research uses a quantitative approach with an experimental method. The population in this study amounted to 357 students. The research sample of 33 students with cluster random sampling technique. Data collection in this study used a questionnaire of student interest in learning. Data were analyzed using t-test with the results of t-calculation of 49.73 compared with t-table 1.693. The results showed that there was an influence of small games on students' interest in learning.
\end{abstract}
ABSTRAK
Masalah dalam penelitian ini adalah rendahnya minat belajar siswa dalam pembelajaran pendidikan jasmani kelas vii di MT's Al-Ahliyah. Penelitian ini bertujuan untuk mengetahui pengaruh permainan kecil terhadap minat belajar siswa. Penelitian ini menggunakan pendekatan kuantitatif dengan metode eksperimen. Populasi dalam penelitian ini berjumlah 357 siswa. Sampel penelitian berjumlah 33 siswa dengan teknik cluster random sampling. Pengumpulan data pada penelitian ini menggunakan Angket minat belajar siswa. Data dianalisis menggunakan uji-t dengan hasil perhitungan t-hitung sebesar 49,73 dibandingkan dengan t-tabel 1,693. Hasil penelitian menunjukkan bahwa terdapat pengaruh permainan kecil terhadap minat belajar siswa.

\section{PENDAHULUAN}

Penerapan permainan kecil diharapkan dapat menumbuhkan minat belajar dalam diri siswa, sehingga dalam melakukan aktivitas pembelajaran pendidikan jasmani, olahraga dan kesehatan tidak ada unsur paksaan dari orang lain melainkan timbul dari dalam diri siswa sendiri. Permainan kecil dalam pembelajaran penjas dapat membuat siswa bergerak dengan sendirinya dan menciptakan suasana dalam pembelajaran penjas yang menyenangkan, menantang dan dapat memberikan sebuah nilai-nilai yang baik yang dapat merubah prilaku, pola pikir dan 


\section{Volume 12 Nomor 2, Juni 2020}

tindakan siswa untuk memecahkan sebuah masalah, selain itu dengan permainan kecil diharapkan siswa mendapatkan kualitas kebugaran tubuh. Permainan kecil ini bisa dilakukan dimanapun dan kapan pun dan permainan kecil ini tidak ada peraturan yang baku dalam penerapannya baik mengenai peraturan permainan, alat yang digunakan, ukuran lapang, maupun durasi waktu. Berbagai macam nilai yang terkandung dalam perminan kecil misalnya: kerjasama, tanggung jawab, percaya diri, menghargai kawan maupun lawan, disiplin, sportif keberanian dll.

"Minat belajar adalah kecenderungan subjek yang menetap untuk merasa tertarik pada bidang studi atau pokok bahasan tertentu dan senang mempelajari materi tersebut" (Muhaimin, 1994:8).

Permainan kecil menurut Carl Bucher (dalam Rustam effendi, 2014: 9) adalah "permianan telah lama dikenal oleh anak-anak dan orang tua karena mampu menggerakkan mereka untuk berlatih, bergembira, dan rileksasi."

Permaian kecil menurut Herbert Spancer (dalam Abdul Salam Hidayat, 2014: 8) adalah "permianan yang disebabkan oleh mengalirnya energi, yaitu tenaga yang belum dipakai dan menumpuk pada anak itu menuntut dimanfaatkan atau dipekerjakan. Sehubungan dengan itu energi tersebut mencair dan mengunggah dalam bentuk permainan". Permianan kecil menurut Karl Gross Spancer (dalam Abdul Salam Hidayat, 2014: 8) menyatakan bahwa "permianan mempunyai tugas biologis, yaitu melatih macam-macam fungsi jasmani dan rohani". Menurut Hartati, dkk (2012: 27) "Permainan kecil yaitu suatu bentuk permainan yang tidak mempunyai peraturan baku, baik mengenai peraturan permainannya, alat-alat yang digunakan, ukuran lapangan maupun lapangan permainannya". Menurut Hartati, dkk (2012: 30) "Permainan kecil memiliki nilai strategis terhadap efektifitas pembelajaran PJOK, bermain juga merupakan bagian yang sangat penting dalam proses pendidikan. Dalam bermain anak dapat menerima banyak rangsang, selain dapat membuat dirinya senang juga dapat menambah pengetahuan anak".

Dari pengertian para ahli diatas maka dapat ditarik kesimpulannya bahwa "Permainan kecil adalah bentuk aktifitas yang sudah lama dikenal oleh anak sebagai bentuk kegiatan yang menyenangkan dan memperbaiki keterampilan jasmani, rasa sosial, percaya diri, peningkatan moral dan spiritual lewat "fair play" dan "sportmanship" atau bermain dengan jujur, sopan dan berjiwa olahragawan sejati."

Berdasarkan pengamatan peneliti menunjukkan bahwa tidak sedikit siswa/i yang kurang minat dalam mengikuti pembelajaran penjas. Demikian pula yang terjadi pada MTs AL-AHLIYAH. Dengan adanya fasilitas dan peralatan olahraga yang cukup memadai untuk siswa, sehingga mampu menarik siswa untuk mengikuti pembelajaran penjas. Namun respon yang diberikan oleh siswa umumnya berbeda-beda, ada yang mengikuti pembelajaran penjas dengan senang hati dan ada pula yang menolak. Penolakan mereka seringkali disertai kebiasaan, lingkungan, dan pergaulan yang mengkondisikan bahwa merupakan beban yang memberatkan siswa. Sehingga siswa dengan sengaja tidak mengikuti pembelajaran penjas dengan tidak membawa seragam olahraga atau pergi ke kantin. Banyak diantara mereka mengeluhkan dengan gaya mengajar yang kurang menarik sehingga minat dari siswa terhadap pembelajaran penjas sangat kurang.

Berdasarkan pertimbangan di atas maka tujuan dalam penelitian ini yaitu untuk mengetahui Pengaruh Permainan Kecil Terhadap Minat Belajar Siswa Dalam Pembelajaran Pendidikan Jasmani Kelas VIII Di MTs Al-Ahliyah.

\section{METODE}

Penelitian ini menggunakan pendekatan kuantitatif dengan metode eksperimen. Dalam penelitian eksperimen ada perlakuan 


\section{e-ISSN: 2657-0703 dan p-ISSN: 2085-5389}

(treatment), sedangkan dalam penelitian naturalistik tidak ada perlakuan. Dengan demikian metode penelitian eksperimen dapat diartikan sebagai metode penelitian yang digunakan untuk mencari pengaruh perlakuan tertentu terhadap yang lain dalam kondisi yang terkendalikan.

Populasi dalam penelitian ini adalah keseluruhan siswa kelas VIII MT's Al-Ahliyah yang berjumlah 357 siswa. Dengan demikian penulis memakai salah satu macam sampel yaitu teknik pada sampel penelitian ini menggunakan sampel cluster random sampling, Menurut Sugiyono (2004:83) cluster random sampling adalah teknik yang digunakan bilamana populasi tidak terdiri dari individu-

individu, melainkan terdiri dari kelompok individu atau cluster. Dalam hal ini sampel dilakukan dengan mengundi seluruh kelas VIII, dan terpilih kelas VIII J dengan jumlah 33 siswa.

Untuk mendapatkan data dalam penelitian ini, Terdapat tiga tahapan pada penelitian ini, yaitu : pre-test, treatment dan posttest. dengan menggunakan Angket Minat Belajar Siswa.

\section{HASIL DAN PEMBAHASAN}

\section{Hasil Nilai Rata-Rata dan Simpangan Baku}

Tabel 1.

Nilai Rata-Rata dan Simpangan Baku

\begin{tabular}{cccc}
\hline Sampel & Periode Tes & Rata-Rata & Simpangan Baku \\
\hline \multirow{2}{*}{ Kelas VIII J } & Tes Awal & 97,48 & 10,224 \\
\cline { 2 - 4 } & Tes Akhir & 109,66 & 7,67
\end{tabular}

Jika dilihat berdasarkan rata-rata hasil skor minat belajar, dengan rata-rata skor untuk minat belajar kelas VIII J sebelum treatment yaitu 97,48 dengan kriteria minat rendah dan untuk minat belajar sesudah treatment yaitu 109,66 dengan kriteria minat sedang, terdapat perbedaan yang cukup tinggi antara sebelum dan sesudah treatment dengan peningkatan yaitu 12,18. Gambaran ini menunjukan bahwa siswa setelah diberi treatment memiliki tingkat minat belajar lebih tinggi dibandingkan sebelum di beri treatment.

Dari temuan tersebut penulis mengidentifikasi bahwa dengan melakukan permainan kecil dalam pemanasan berpengaruh pada minat belajar penjas siswa.

\section{Hasil Uji Normalitas}

Tabel 2.

Hasil Uji Normalitas Data

\begin{tabular}{ccccc}
\hline Sampel & Periode Tes & L $_{\mathbf{0}}$ Hitung & L Tabel & Simpulan \\
\hline \multirow{2}{*}{ Kelas VIII J } & Tes Awal & 0,0136 & 0.154 & Normal \\
\cline { 2 - 5 } & Tes Akhir & 0,0211 & 0.154 & Normal \\
\hline
\end{tabular}

Nilai $\mathrm{L}_{0}$ Hitung kelas VIII $\mathrm{J}$ adalah 0,0136 dengan taraf nyata 0.05 sedangkan dari daftar tabel di dapat $\mathrm{L}_{\text {Tabel }}=0.154$ yang lebih besar dari $\mathrm{L}_{\text {Hitung }}=0,0136$ sehingga hipotesis diterima.. Dengan demikian tes awal kelas VIII J berdistribusi normal. Sedangkan dari 


\section{Volume 12 Nomor 2, Juni 2020}

daftar tabel diatas pada tes akhir di dapat $\mathrm{L}_{0}$ Hitung 0,0211 dengan taraf nyata 0.05 dan $\mathrm{N}=33$ sedangkan dari daftar tabel di dapat $\mathrm{L}_{\text {Tabel }}=0.154$ yang lebih besar dari $\mathrm{L}_{0}$ Hitung
$=0,0211$ sehingga hipotesis diterima. Dengan demikian tes kelas VIII J berdistribusi normal.

\section{Hasil Homogenitas}

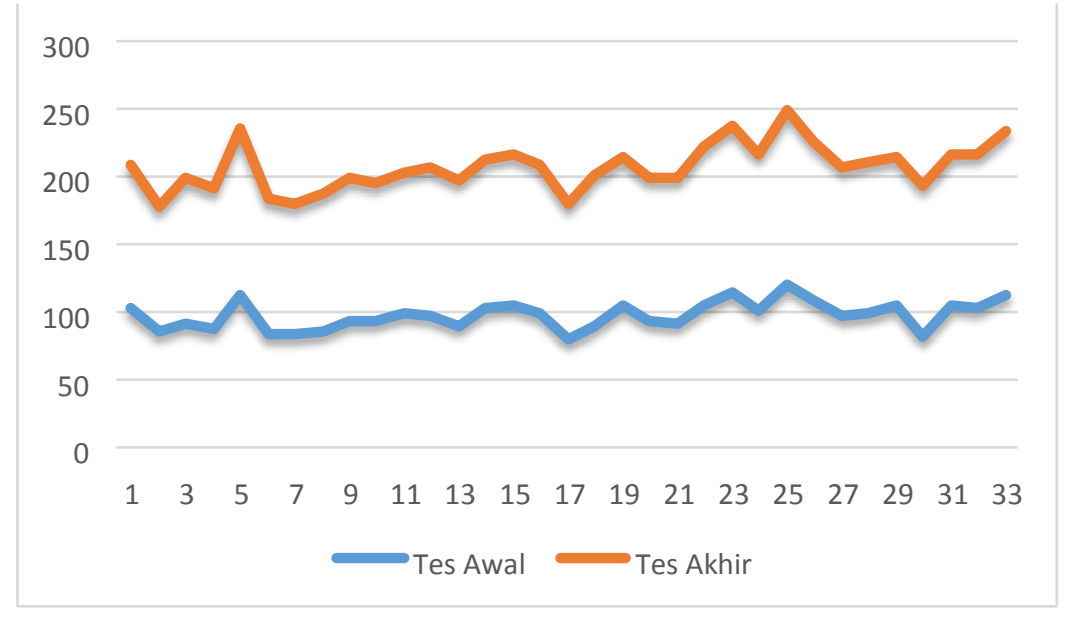

Gambar 1.

Hasil Uji Homogenitas

\section{Hasil Uji Hipotesis (Signifikan)}

Tabel 3.

Hasil Uji Beda Dua Rata-Rata (Signifikan)

\begin{tabular}{ccccc}
\hline Sampel & Periode Tes & T Hitung & T Tabel & Simpulan \\
\hline \multirow{2}{*}{ Kelas VIII J } & Tes Awal & 49,73 & 1,693 & Signifikan \\
\cline { 2 - 5 } & Tes Akhir & 53,46 & 1,693 & Signifikan \\
\hline
\end{tabular}

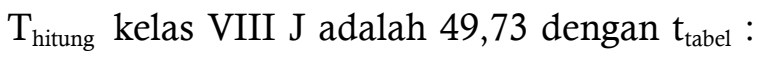
$\alpha=0,05$ dan $\mathrm{db}=33-1=32$ adalah $\mathrm{T}_{\text {tabel }}$ adalah 1,693 yang artinya lebih kecil dari $\mathrm{T}_{\text {hitung }} 49,73$ sehingga uji signifikan diterima. Pada tabel 4.4 juga dapat di lihat tes akhir kelas VIII $\mathrm{J}$ bahwa $\mathrm{T}_{\text {hitung }}$ nya adalah 53,46 dengan $t_{\text {tabel }}: \alpha=0,05$ dan $d b=33-1=32$ adalah $\mathrm{T}_{\text {tabel }}$ adalah 1,693 yang artinya lebih kecil dari $\mathrm{T}_{\text {hitung }} 53,46$ sehingga uji signifikan diterima.

\section{SIMPULAN DAN SARAN}

Berdasarkan pada latar belakang masalah, tinjauan teoritis, penentuan metode penelitian, pengolahan dan analisis data sebagai deskripsi dari variabel penelitian, serta perumusan diskusi penemuan, maka dalam penelitian ini penulis dapat menyimpulkan sebagai berikut: terdapat peningkatan yang signifikan antara permainan kecil dengan minat belajar siswa dalam pembelajaran pendidikan jasmani (penjas) siswa kelas VIII MT's Al Ahliyah 2019/2020. Gambaran ini menunjukan bahwa peserta didik setelah diberi treatment memiliki tingkat minat belajar lebih tinggi dibandingkan sebelum di beri treatment, hal ini dapat dibuktikan lewat uji signifikan yang sudah dihitung oleh peneliti. Tes awal yakni $\mathrm{T}_{\text {hitung }} 49,73$ dan tes akhir yakni $\mathrm{T}_{\text {hitung }} 53,46$ 


\section{e-ISSN: 2657-0703 dan p-ISSN: 2085-5389}

sedangkan $\mathrm{T}_{\text {tabel }}$ nya adalah 1,693 yang artinya $\mathrm{T}_{\text {tabel }}$ lebih kecil dari $\mathrm{T}_{\text {hitung }}$ sehingga uji signifikan diterima dengan pengaruh atau peningkatan 7,6\% pada kelas VIII J. Dari hasil analisis data tersebut membuktikan bahwa terdapat pengaruh permainan kecil terhadap minat belajar siswa dalam pembelajaran penjas kelas VIII di MT's AlAhliyah.

\section{DAFTAR RUJUKAN}

Ismaya Bambang. (2015). Pengelolaan Pendidikan, Karawang

Salam Abdul. (2016). Teori Bermaian Dalam Pendidikan Jasmani Dan Permainan Tradisional. Karawang: Multi Kreasindo

Effendi Rustam. (2014). Teori Dan Praktek Permainan Dalam Pembelajaran, Karawang

Sugiono. (2012). Statistika untuk penelitian, Bandung : Alfabeta

Sugiyono, (2013). Metode Penelitian Pendidikan Pendekatan Kuantitatif, Kualitatif, dan R\&D. Bandung: Alfabeta

Sugiyono, (2015). Metode Penelitian Pendidikan (Pendekatan Kuantitatif, Kualitatif dan R\&D. Penerbit CV. Alfabeta: Bandung.

Sobari Fauzi. (2017). Pengaruh Minat Belajar Terhadap Hasil Belajar Siswa Pada Mata Pelajaran Ilmu Pengetahuan Sosial di SMP Negeri 1 Jonggol. Disertai Sarjana pada FITK UIN Jakarta: tidak diterbitkan.

Sutisna M.D. (2017). Pengaruh Permainan Tradisional Dalam Pemanasan Terhadap Motivasi Belajar Siswa Dalam Pembelajaran Pendidikan
Jasmani Olahraga dan Kesehatan Siswa Kelas VII SMP Negeri 4 Klari Kabupaten Karawang. Disertasi Sarjana Pada FKIP UNSIKA Karawang: tidak diterbitkan. 